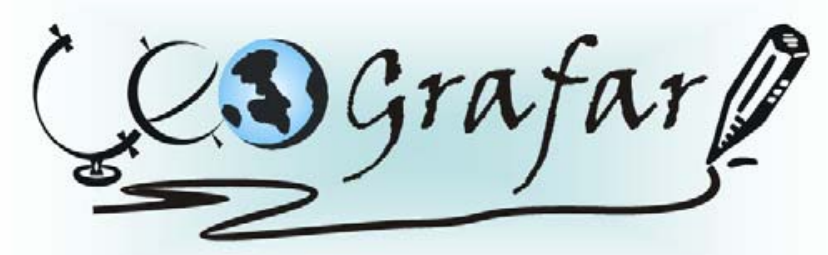

Revista Eletrônica do Programa de Pós-Graduação em Geografla - UFPR

\title{
ANÁLISE DOS ASPECTOS FÍSICOS E DAS INTERVENÇÕES ANTRÓPICAS DA BACIA HIDROGRÁFICA DO ARROIO KRUZE -RS
}

\author{
Adriana de Fátima Penteado ${ }^{1}$ \\ Nina Simone Vilaverde Moura Fujimoto ${ }^{2}$
}

\section{RESUMO}

O presente trabalho tem por objetivo geral o estudo ambiental da bacia hidrográfica do arroio Kruze, localizada entre as latitudes de $29^{\circ} 45^{\prime}$ e $29^{\circ} 50^{\prime}$ sul e longitudes de $51^{\circ} 03^{\prime}$ e $51^{\circ} 09^{\prime}$ oeste, região metropolitana de Porto Alegre - RMPA. Para atingir o objetivo geral deste trabalho, desenvolveram-se os seguintes objetivos específicos: análise do quadro geomorfológico, geológico e pedológico, em âmbito regional; no nível local: elaboração e análise dos mapas geomorfológico, de declividade, hipsométrico e do modelo 3D do terreno, representando as diferentes formas do relevo e os processos a ele relacionados; elaboração e análise do mapa de uso e ocupação do solo e das Transgressões ao Código Florestal. A metodologia de trabalho compreendeu revisão bibliográfica, buscando a relação dos diferentes itens analisados com a realidade regional e local; trabalhos de campo para o levantamento e a aferição das informações obtidas; e a elaboração dos mapas acima citados, todos em ambiente computacional de SIG - Sistema de Informações Geográficas. A partir dos levantamentos e das análises elaboradas, constatou-se que os problemas mais significativos da bacia hidrográfica do arroio Kruze são as ocupações irregulares, a poluição hídrica, a impermeabilização do solo, a extração mineral irregular, a erosão, o assoreamento e a destruição dos banhados. Partindo dessas informações é possível traçar estratégias de controle e/ou de resolução dos problemas que estão inseridos numa escala mais ampla que o recorte de estudo.

PALAVRAS-CHAVE: bacia hidrográfica; degradação ambiental; região metropolitana de Porto Alegre.

\footnotetext{
${ }^{1}$ Mestre em geografia (UFRGS) - e-mail: adripent@pop.com.br

${ }^{2}$ Profa. Dra do Programa de Pós Graduação (UFRGS) - e-mail: nina.fujimoto@ufrgs.br
} 


\title{
PHYSICAL ASPECTS AND ANTROPIC INTERVENTIONS ANALYSIS OF ARROIO KRUZE HIDROGRAFIC BASIN - RS.
}

\begin{abstract}
The present work has as general objective the environmental study of arroio Kruze hidrographic basin, located between latitudes $29^{\circ} 45^{\prime}$ and $29^{\circ} 50^{\prime} \mathrm{S}$ and longitudes $51^{\circ}$ $03^{\prime}$ and $51^{\circ} 09^{\prime} \mathrm{W}$, which belong to Porto Alegre metropolitan region (RMPA). To get the general purpose of this work, the following specific objectives were developed: geomorphologic, geologic and pedologic analysis; research about regional; and local: elaboration and analysis of geomorphological, slopes gradients and hypsometric maps, and digital elevation models, representing the different landforms and processes; elaboration and analysis of land use and soil occupation and Forest Code infringements maps. The methodology of the this work corresponds to bibliographic revision, searching the relationship between the different analyzed issues and the local and regional reality; gathered informations in field works; and the final elaboration of all above mentioned maps using GIS methods. Through the gathered and analyzed informations and data, it has verified that the most significant problems found in arroio Kruze hydrographic basin are irregular occupations, hydro pollution, soil impermeabialization, irregular mineral extraction, erosion, assoreament and destruction of wetlands. May have in setting about this informations, to setlle resolutions and controling strategies for problems in wider scales than this cases study.
\end{abstract}

KEY WORDS: hydrographic basin, environmental degradation, metropolitan region of Porto Alegre. 


\section{INTRODUÇÃO}

O objetivo do presente trabalho é o estudo ambiental da bacia hidrográfica do arroio Kruze, situada na Região Metropolitana de Porto Alegre. O SIG - Sistema de Informações Georreferenciadas compreendeu ferramenta básica para a elaboração dos mapas físicos e de uso e ocupação do solo, buscando um estudo integrado das informações.

O único mapa gerado a partir do cruzamento de informações corresponde ao mapa das Transgressões ao Código Florestal, onde foram utilizados os layers de informação gerados no mapa de uso e ocupação do solo (vegetação arbórea e de campo). Para os demais mapas, o cruzamento serviu apenas para fins de análise, não tendo sido gerado mapa adicional.

A importância de um estudo integrado, deve-se principalmente ao fato da crescente intervenção humana nos sistemas ambientais naturais causando assim o desequilíbrio. Porém, além de dinâmica a natureza está interligada, sendo que uma intervenção inadequada, por exemplo, numa bacia hidrográfica, pode trazer conseqüências às outras que estão integradas a mesma.

A bacia hidrográfica como recorte de estudo deve-se ao fato de que esta adotada como unidade de planejamento e gestão, integrada às políticas públicas e a sociedade, tende a tornar os problemas futuros menos impactantes, tanto no custo ambiental como no campo social.

Segundo Botelho (1999), a bacia hidrográfica sendo entendida como célula básica da análise ambiental, permite reconhecer e avaliar seus diversos componentes e os processos de interação que nela ocorrem.

Quanto ao SIG este compreende uma importante ferramenta que busca a realização de levantamentos, análises e cruzamentos de informações georreferenciadas, visando o planejamento, o manejo e/ou o gerenciamento de um espaço específico. É atualmente, uma ferramenta viável para o estudo do ambiente, planejamento ambiental e gerenciamento dos recursos naturais.

\subsection{Objetivos}

O presente trabalho teve como objetivo principal a análise ambiental da bacia hidrográfica do arroio Kruze relacionando aspectos naturais e antrópicos.

Para atingir o objetivo geral deste trabalho, desenvolveram-se os seguintes objetivos específicos: análise do quadro geomorfológico, geológico e pedológico no âmbito regional; elaboração e análise dos mapas geomorfológico, declividade, hipsométrico e modelo 3D do terreno, representando as diferentes formas do relevo e os processos a ele relacionados; elaboração e análise do mapa de uso e ocupação do solo, e mapa das Transgressões ao Código Florestal de 1965.

\subsection{Localização e Caracterização Geral da Área de Estudo}

A área de estudo deste trabalho é a bacia hidrográfica do arroio Kruze, localizada entre as latitudes de $29^{\circ} 45^{\prime}$ e $29^{\circ} 50^{\prime}$ sul e longitudes de $51^{\circ} 03^{\prime}$ e $51^{\circ} 09^{\prime}$ oeste, entre os municípios de São Leopoldo, Sapucaia do Sul e Novo Hamburgo (Figura 1), os quais pertencem à região metropolitana de Porto Alegre - RMPA, capital do estado do Rio Grande do Sul.

No município de São Leopoldo está localizada a maior área da bacia hidrográfica do arroio Kruze $\left(18,46 \mathrm{~km}^{2}\right)$, incluindo o perímetro urbano $\left(14,36 \mathrm{~km}^{2}\right)$ e rural $\left(4,1 \mathrm{~km}^{2}\right)$. Em Sapucaia do Sul, estão localizadas algumas nascentes ao sul e sudoeste da bacia $\left(5,2 \mathrm{~km}^{2}\right)$, com área mais representativa para o perímetro rural $\left(4,7 \mathrm{~km}^{2}\right)$. Já em Novo 
Hamburgo, a bacia hidrográfica do arroio Kruze, compreende uma pequena área (1,07 $\mathrm{km}^{2}$ ), incluindo somente o perímetro rural. Os três municípios possuem alta taxa de urbanização, esta próxima à saturação. São cidades que se desenvolveram, de forma mais expressiva, a partir da imigração alemã.

A bacia hidrográfica do arroio Kruze tem área aproximada de $24,74 \mathrm{~km}^{2}$, constituindo-se em uma sub-bacia da bacia hidrográfica do rio dos Sinos, a qual se interliga com o lago Guaíba. A bacia hidrográfica do rio dos Sinos é uma das mais importantes do Estado, formando com outras oito sub-bacias hidrográficas (Vacacaí Mirim, Alto Jacuí, Baixo Jacuí, Taquari-Antas, Caí, Gravataí, Guaíba, Pardo) a região hidrográfica do Guaíba, abrangendo um total de 251 municípios. Devido à intensa atividade econômica na região, há uma forte pressão para a ocupação do solo, que conta com $63,9 \%$ da população do estado, causando demanda expressiva sobre os recursos naturais.

\section{FIGURA 1: LOCALIZAÇÃO DA BACIA HIDROGRÁFICA DO ARROIO KRUZE}

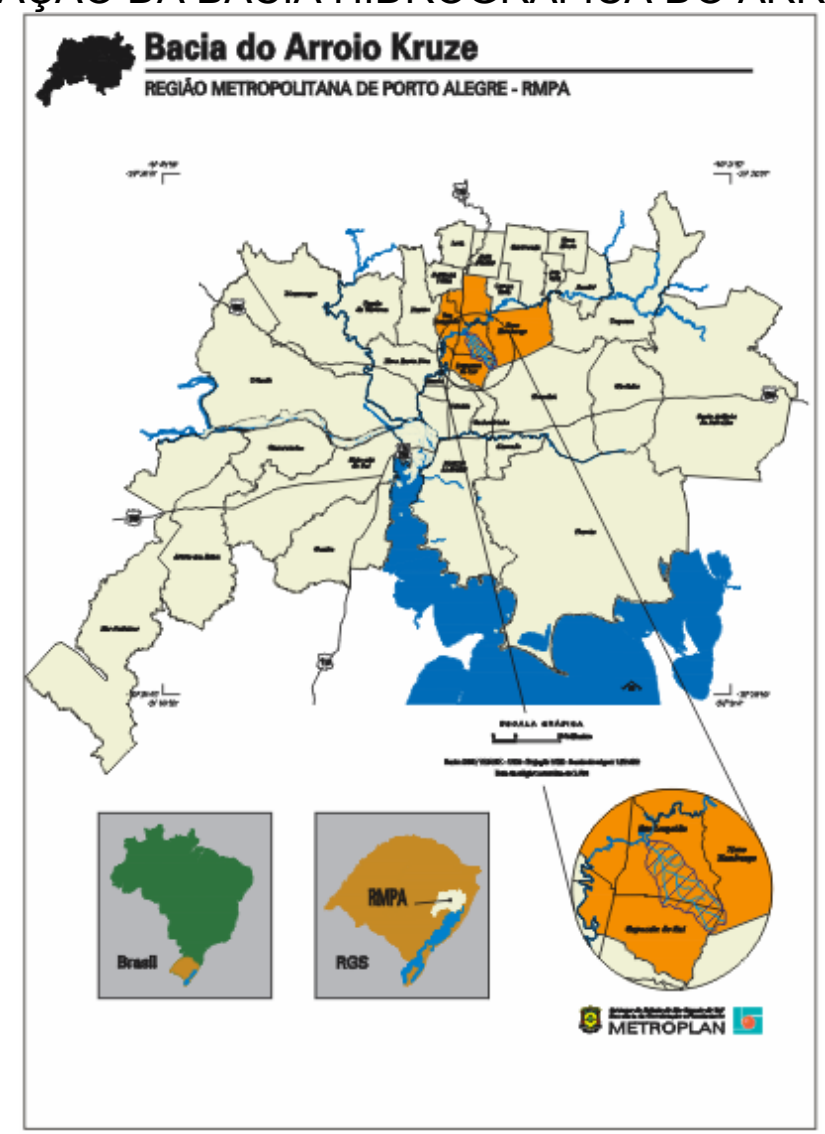

Fonte: METROPLAN, 2004.

A partir da metodologia de Strahler (1952), a bacia hidrográfica do arroio Kruze foi definida como uma bacia de $4^{\mathrm{a}}$ ordem, possuindo aproximadamente 143 canais de $1^{\mathrm{a}}$ ordem entre rios efêmeros, intermitentes e perenes, 41 canais de $2^{\mathrm{a}}$ ordem e 8 canais de $3^{\mathrm{a}}$ ordem. A profundidade da lâmina de água é, em média, de $40 \mathrm{~cm}$, mesmo no canal de $4^{\circ}$ ordem, caracterizando dessa forma uma baixa vazão. Esta informação é baseada em aferição visual realizada por meio dos trabalhos de campo na bacia hidrográfica do arroio Kruze, onde não foi elaborada medida da vazão seguindo critérios técnicos. O período de realização das etapas de campo foi nos meses de maio e junho de 2005. Segundo informação da Rede de Estações de Climatologia Urbana do Rio Grande do Sul (2004), o mês de maio se constitui em período seco, e o mês de junho como período chuvoso. 


\subsection{Justificativas}

O quadro 1, procura sistematizar tanto os principais problemas da área de estudo, quanto os fatores complicadores e as conseqüências trazidas para o local. A maneira como foi organizado o quadro, de forma alguma encerra as inúmeras relações que podem ser feitas a partir dos dados apresentados, o mesmo apresenta uma síntese e possibilita outras análises, mesmo aquelas não descritas nesse trabalho.

QUADRO 1: PROBLEMAS SÓCIO-AMBIENTAIS DA ÁREA DE ESTUDO

\begin{tabular}{|c|c|c|c|}
\hline \multicolumn{4}{|c|}{ PRINCIPAIS PR OBLEMAS NA ÁREA DE EST UDO } \\
\hline AGENTES & ESPECÍFICO & COMPLICADORES & CONSEQUÊHCLAS \\
\hline \multicolumn{4}{|c|}{ OCUPAÇÖE S IRREGULARE S } \\
\hline $\begin{array}{l}\text { População de } \\
\text { b aixa rend a }\end{array}$ & $\begin{array}{c}\text { Á re as de banhado } \\
\text { Margem dos arroios } \\
\text { Á rea de Proteção Permanente } \\
\text { (Mono do Paula) }\end{array}$ & $\begin{array}{l}\text { Consciência e conhecimento } \\
\text { "amb intal" deficiente. } \\
\text { Défir it hab itacional } \\
\text { Más cond içóes de moradia }\end{array}$ & $\begin{array}{l}\text { Baixa qualid ade de vid a principalmente } \\
\text { daqueles que estão mais próximo ao ro } \\
\text { pohido. Em alguns casos o que } \\
\text { pohi é o que sofre diretamente } \\
\text { como prob lema. } \\
\text { Destruição gradual dos b anhados } \\
\text { Desmatamento }\end{array}$ \\
\hline \multicolumn{4}{|c|}{ POLUIÇĂO } \\
\hline Á reas re sidenciais & esgoto doméstico e lixo & $\begin{array}{l}\text { Geração de empre gos pelas } \\
\text { empresas poluidoras o que } \\
\text { inibe a ação do governo }\end{array}$ & $\begin{array}{l}\text { Pohição, assore amento e } \\
\text { altração da dinâmica flu vial } \\
\text { Perd a da qualidade e por consequência } \\
\text { da quantid ade de água dos arroios }\end{array}$ \\
\hline \multicolumn{4}{|c|}{ EXTR AÇĂO MINERAL IRRE GULAR (Morr o do Paula) } \\
\hline $\begin{array}{c}\text { Principalmente } \\
\text { moradores do } \\
\text { Morro do Paula } \\
\text { "Empresas" irregulares }\end{array}$ & $\begin{array}{c}\text { Á re ade Proteção Permanente } \\
\text { (M orro do Paula) }\end{array}$ & $\begin{array}{c}\text { Extração irregular no Morno é a } \\
\text { principal fonte de renda da região } \\
\text { Problemas de litígio incluindo } \\
\text { o Moro } \\
\text { Proibição legal de criação de } \\
\text { infra-estrutura no Moro } \\
\text { por tratar-se de uma APP } \\
\text { Os restos da extração ("bota- fora") } \\
\text { são jogados nas encostas do Morro. } \\
\text { Local inseguro }\end{array}$ & $\begin{array}{l}\text { Mod ifica ção express iva na } \\
\text { morfolog da do Morro do Panla. } \\
\text { Ass ore amento dos arroios. } \\
\text { Dificuldade de algumas ações positivas } \\
\text { no Morno devido à violência } \\
\text { Multa à prefeitura (São Leopoldo) } \\
\text { devido à existênc ia } \\
\text { de pedreiras irreg ulares }\end{array}$ \\
\hline
\end{tabular}

Fonte: Dados obtidos em levantamento de campo.

Elaboração: Adriana Penteado, 2006.

Estas informações foram obtidas por meio de trabalhos de campo e entrevistas nas mais diferentes oportunidades. Posteriormente serão feitas discussões e análises dos principais itens.

\section{MATERIAIS E MÉTODOS}

\subsection{Materiais}

- Mapas do Levantamento Aerofotogramétrico da Região Metropolitana de Porto Alegre. Escala 1: 10000 de 1972;

- Fotografias Aéreas em preto e branco. Escala original 1: 8000 de 1991. Ambos fornecidos pela METROPLAN - Fundação de Planejamento Metropolitano e Regional;

- Mapa Geológico, Geomorfológico, Pedológico e do Relevo. Escala 1: 250000. Fonte: Projeto RADAMBRASIL, 1986; 
- Fotografias Aéreas Coloridas. Escala original 1: 12000 de 2002. Fornecidas pela Secretaria Municipal de Meio Ambiente de São Leopoldo- SEMMAM;

- Envi 4.0 para o georreferenciamento das fotografias aéreas e da base cartográfica;

- Arc View 3.2 para a digitalização, elaboração e análise das informações. Ambos fornecidos pelo Departamento de Geodésia do laboratório de Geoprocessamento da UFRGS.

\subsection{Métodos}

\subsubsection{Teórico Metodológico}

O estudo ambiental da bacia hidrográfica do arroio Kruze foi baseado na proposta metodológica de Fragilidade Ambiental de Ross (1994), que propõe uma analise integrada dos ambientes naturais e antropizados.

Em escala de detalhe não havia mapas referentes ao solo e a geologia, e pela falta de tempo hábil para a elaboração dos mesmos, utilizaram-se os levantamentos elaborados pelo Projeto RADAMBRASIL (1986), para a caracterização dos solos, geologia e geomorfologia no âmbito regional, este último elaborado em escala de detalhe.

No âmbito local, para o estudo do relevo, elaboraram-se os mapas de declividade, hipsométrico, modelo 3D do relevo e geomorfológico, aqueles servindo de base para uma melhor compreensão deste. Em relação ao ambiente antrópico foram elaborados os mapas de uso e ocupação do solo e das Transgressões ao Código Florestal.

Para o mapa de declividade utilizaram-se das classes de declividade que compreenderam os seguintes intervalos; < 5, 5 -12, 12-30, 30-47 e > 47.

Em relação ao mapa geomorfológico, utilizou-se a proposta metodológica de táxons elaborada por Ross (1992), a importância da definição de táxons se dá pela maior facilidade em operacionalizar uma pesquisa geomorfológica, tendo como apoio a cartografia das formas do relevo de diferentes tamanhos.

O mapa de uso e ocupação do solo foi elaborado considerando, entre outros fatores, o grau de adensamento urbano, sendo classificadas áreas de ocupação adensada e áreas de ocupação rarefeita. O adensamento urbano é um fator muito importante do ponto de vista ambiental, pois interfere em vários fatores como por exemplo no grau de impermeabilização do solo. O mapa das Transgressões ao Código Florestal partiu dos parâmetros desta lei para a sua elaboração.

\subsubsection{Operacional}

Para a elaboração dos mapas hipsométrico, de declividade e Modelo 3D do Terreno, foi necessária a escanerização, o georreferenciamento, a digitalização e a cotação das curvas de nível e topos. Para o mapa geomorfológico antes dos procedimentos acima citados, foram utilizadas fotografias aéreas de 1991 contando com a técnica de estereoscopia para extrair a informação desejada, bem como trabalho de campo.

Para o mapa de uso e ocupação do solo, além de monitoramento de campo, foram utilizadas fotografias aéreas de 2002, que foram georreferenciadas e digitalizadas via tela. Utilizou-se como material de apoio imagens e cartas produzidas anteriormente.

Para a elaboração do mapa das transgressões, partiu-se dos parâmetros do Código Florestal, criando-se um buffer de 30 metros para a mata ciliar (considerando que os rios da bacia hidrográfica do arroio Kruze não ultrapassam dez metros de largura) e buffer com raio de 50 metros para as nascentes. Posteriormente cruzaram-se os layers de vegetação arbórea e de campo (confeccionados no mapa de uso e ocupação do solo) com as áreas de buffer, identificando assim as transgressões. 


\section{ANÁLISE REGIONAL GEOMORFOLÓGICA, GEOLÓGICA E PEDOLÓGICA}

\subsection{Geomorfologia}

A bacia hidrográfica do arroio Kruze, segundo a compartimentação do relevo do Projeto RADAMBRASIL (1986), insere nas unidades geomorfológicas Planície Lagunar, Patamares da Serra Geral e Depressão do Rio Jacuí conforme figura 2. A partir desta definição serão feitas algumas considerações em relação às unidades geomorfológicas da área de estudo.

\section{FIGURA 2: ADAPTAÇÃO DO MAPA GEOMORFOLÓGICO RADAMBRASIL (1986).}

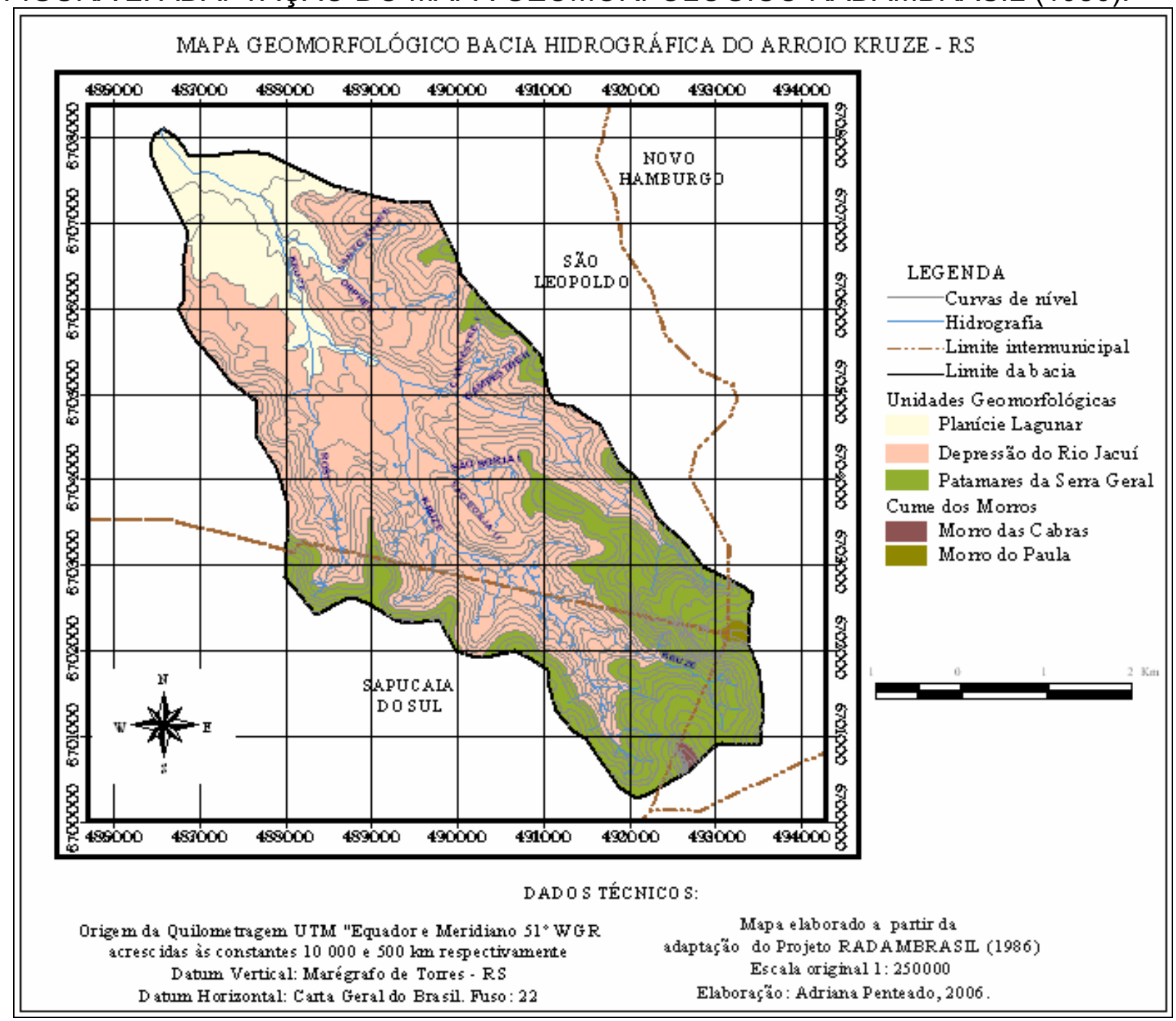

Fonte : RADAMBRASIL, 1986.

Adaptação: Adriana Penteado, 2006.

A Unidade Geomorfológica Planície Lagunar caracteriza-se por ser uma área plana, homogênea e sem dissecação, onde dominam os modelados de acumulação representados pelas planícies e terraços lacustres.

A Unidade Geomorfológica Patamares da Serra Geral engloba formas em colinas com pequeno aprofundamento dos vales fluviais, formas de relevo que apresentam forte controle estrutural, e localmente ocorrem formas planares. À borda da Unidade Geomorfológica Patamares da Serra Geral observa-se uma série de morros testemunhos que avançam sobre a Unidade Geomorfológica Depressão Rio Jacuí. 
A Unidade Geomorfológica Depressão Rio Jacuí caracteriza-se por não apresentar grandes variações altimétricas, dando à paisagem um caráter monótono, onde dominam formas alongadas de topos convexos. Ao lado dessas formas ocorrem vastas superfícies planas, recobertas por colúvios, com dissecação incipiente.

\subsection{Geologia}

Segundo relatório do projeto RADAMBRASIL (1986), a bacia hidrográfica do arroio Kruze é representada pela cobertura sedimentar cenozóica e pela cobertura vulcano sedimentar da bacia do Paraná.

A Cobertura Sedimentar Cenozóica caracteriza-se pela presença de depósitos aluvionares recentes ocupando as calhas dos rios atuais, constituídos de areias, cascalhos, silte e argilas. Esta mais diretamente relacionada à Unidade Geomorfológica Planície Lagunar.

A cobertura vulcano-sedimentar da bacia do Paraná compreende, para a área de estudo, a Formação Botucatu e a Formação Sanga do Cabral, sendo que a primeira formação está mais diretamente relacionada à Unidade Geomorfológica Patamares da Serra Geral e a segunda à Unidade Geomorfológica Depressão do Rio Jacuí.

A Formação Botucatu segundo Ramos (1975), é predominantemente eólica de origem, característica em toda a Bacia do Paraná, compreendendo um dos grandes eventos climáticos ocorrido no Mesozóico.

Segundo Frank (1989), que realizou estudos na região de São Leopoldo, o arenito Botucatu apresenta-se em elevações onde são constatadas espessuras entre 100 e 130 metros.

Ainda segundo Ramos (1975), quando silicificados, os arenitos mantêm topografia acidentada, com cotas elevadas, constituindo verdadeiras feições de "cuestas" dissecadas, com freqüência "morros testemunhos" nas faces íngremes.

Andreis, Bossi e Montardo (1980) Apud Frank (1989), utilizaram a denominação Rosário do Sul na categoria de grupo, subdividindo-o nas Formações Santa Maria, Caturrita e Sanga do Cabral, esta situada na área de estudo.

A Formação Sanga do Cabral ocorreu sob regime fluvial, iniciando o assoreamento da bacia sedimentar do Paraná. Na área de estudo está presente nas cotas abaixo dos valores de 100 a 130 metros, possuindo em sua maioria, colinas suaves, de média altitude, configurando-se em paisagens onduladas.

A diferença básica entre a Formação Sanga do Cabral e Formação Botucatu diz respeito à resistência diferenciada entre uma e outra. A Formação Sanga do Cabral apresenta-se mais friável, sendo assim mais facilmente intemperizada. A maior resistência do Botucatu, em comparação com a Formação Sanga do Cabral, pode ser verificada pela presença de morros de maior altitude.

\subsection{Solos}

Em relação aos solos da área de estudo, estes foram identificados a partir do Projeto RADAMBRASIL (1986), e renomeados segundo o Sistema Brasileiro de Classificação de Solos da EMBRAPA (1999). Na área de estudo foram identificados o neossolo flúvico e quartzarênico e o argissolo vermelho e vermelho amarelo.

\subsubsection{Neossolo Flúvico e Neossolo Quartzarênico}

O Neossolo Flúvico possui como características principais solos derivados de sedimentos aluviais com horizonte A firme sobre horizonte $\mathrm{C}$ constituído de camadas estratificadas. 
O Neossolo Quartzarênico é um solo com presença de lençol freático elevado durante grande parte do ano, na maioria dos anos, imperfeitamente ou mal drenados.

Esses solos possuem limitação tanto para a ocupação quanto para a agricultura, devido às condições de drenagem e freqüente inundação. Pelas características peculiares desses solos, pode-se dizer que estes estão localizados na foz do arroio Kruze, compreendendo a planície de inundação do rio dos Sinos.

Estão mais diretamente relacionados à Unidade Geomorfológica Planície Lagunar.

\subsubsection{Argissolo vermelho-amarelo e argissolo vermelho}

Em geral uma das características mais importantes do argissolo refere-se à presença do horizonte $\mathrm{B}$ textural, compreendendo um solo susceptível à erosão, devido à diferença textural entre o horizonte $A$ mais arenoso e o horizonte $B$ mais argiloso, provocando num primeiro momento a erosão do horizonte A que concentra grande quantidade de matéria orgânica. Os argissolos de textura arenosa/média ou de textura arenosa/argilosa são muito suscetíveis ao ravinamento, fato evidenciado na área de estudo.

Em relação ao argissolo vermelho amarelo, na Depressão Central Gaúcha as principais ocorrências localizam-se ao norte de Porto Alegre, onde são derivados das Formações Botucatu e Rosário do Sul. Em geral predominam os solos de baixa fertilidade natural.

O argissolo vermelho na Depressão Central Gaúcha desenvolveu-se em arenitos, siltitos e lamitos de diferentes formações geológicas, ocupando quase sempre as cotas mais elevadas dessa região geomorfológica. Perfis com menor diferenciação textural ocorrem à margem esquerda e direita do rio Jacuí, desenvolvendo-se sobre arenitos da Formação Rosário do Sul, ocupando áreas de relevo suave ondulado e ondulado.

Apresentam horizonte A moderado e proeminente, e mesmo nos perfis bem diferenciados em cor, dificilmente ocorre mudança textural abrupta. Predomina nesta área como um todo a utilização com pastagens, sendo muito expressivos os cultivos anuais e florestamentos, principalmente de eucaliptos.

Estes solos estão mais diretamente relacionados à Unidade Geomorfológica Depressão do Rio Jacuí e Patamares da Serra Geral.

\section{ANÁLISE DAS FORMAS E DAS PRINCIPAIS ALTERAÇÕES NO RELEVO E NA REDE HÍDRICA DA BACIA HIDROGRÁFICA DO ARROIO KRUZE}

\subsection{Hipsometria}

Localmente, verificou-se que a bacia hidrográfica do arroio Kruze possui cerca de $80 \%$ de sua área com até 100 metros de altitude, caracterizando um relevo suave.

As áreas mais elevadas compreendem as altitudes que variam de 280 a 300 metros, constituídas pela Formação Botucatu, com presença de morros testemunhos.

\subsection{Declividade}

De forma geral, na bacia hidrográfica do arroio Kruze predominam as classes de declividade que variam de 0 a $5 \%$ e 5 e $12 \%$. Dessa forma, as características do relevo não compreendem um impedimento para o avanço da ocupação.

As classes de declividade de 30 a $47 \%$ somente são verificadas nas escarpas de morros da Formação Botucatu. As declividades acima de 47 \% não foram encontradas na área de estudo. 
Revista Eletrônica Geografar, Curitiba, v.1, n.1, p. 01-19, jul./dez. 2006

A declividade não e um fator determinante no que se refere aos processos erosivos da área de estudo, mas a característica dos solos.

\subsection{Geomorfologia}

As unidades identificadas na análise geomorfológica da área de estudo, estão representadas na figura 3 .

\section{FIGURA 3: MAPA GEOMORFOLÓGICO DA BACIA HIDROGRAFIA DO ARROIO} KURZE - RS

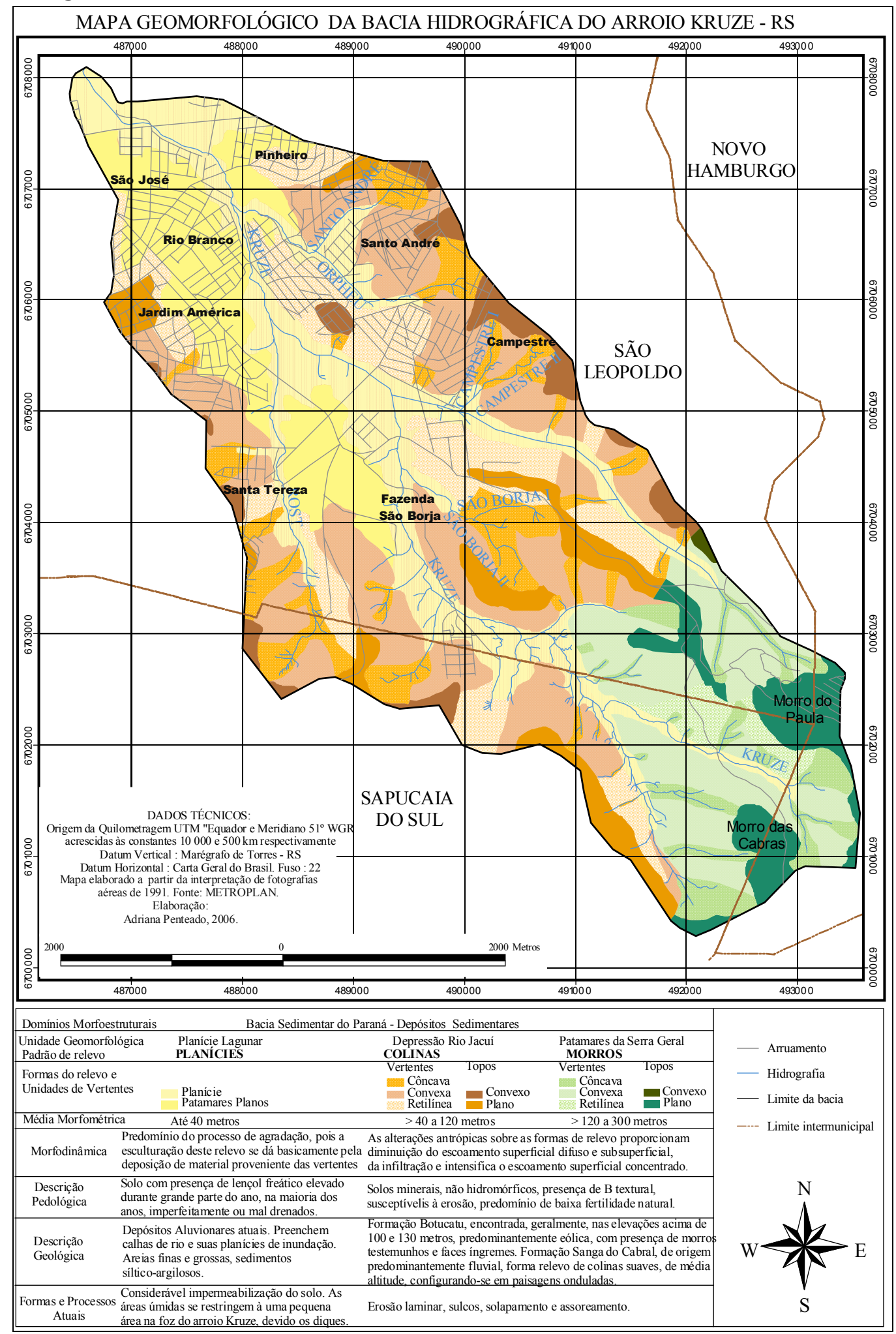




\subsubsection{Planície}

Caracteriza-se por ser uma área plana, homogênea e sem dissecação, sobre sedimentos do quaternário, com o lençol freático próximo à superfície ou aflorante, e em alguns casos permanece permanentemente alagada. Segundo Diniz (2002), corresponde à planície aluvial do rio dos Sinos e arroio Kruze. Com baixa declividade e baixa drenabilidade, estando sujeitas a enchentes por ocasião do extravasamento dos arroios.

Uma ocupação irregular inserida nesta área refere-se à ocupação na chamada mata do arroio Kruze. As pessoas instaladas neste local sofrem com constantes alagamentos. Segundo informação do Sr. Jair, que trabalha nas bombas de captação de água do SEMAE - Serviço de Abastecimento de Água e Esgoto, localizadas a poucos metros das ocupações, houve casos de famílias que foram resgatadas de barco em ocasião do extravasamento do rio dos Sinos, quando este esteve mas ou menos dois metros acima de seu nível normal.

\subsubsection{Patamares planos}

Caracterizam-se por não apresentar grandes variações altimétricas, de 10 a 40 metros em média, com características homogêneas. Com vastas superfícies planas, recobertas por colúvios, com dissecação incipiente. A friabilidade do material superficial favorece a ocorrência de intenso processo erosivo.

Estão localizados, nos bairros: São José, Jardim América, Pinheiro e Rio Branco, correspondendo, em sua maioria às áreas de uso adensado e à parte da zona industrial da área de estudo.

\subsubsection{Colinas}

A altimetria varia em média de 40 a 80 metros, chegando a 120 metros nos topos. Está inserida, predominantemente, na Formação Sanga do Cabral.

As colinas são consideradas de fraca dissecação. Nas áreas de erosão acelerada, devido à ação antrópica, predomina a ocorrência de sulcos e ravinas. Nas áreas onde ainda se preserva a vegetação natural, predomina o escoamento difuso e a infiltração, com morfodinâmica pouco estável.

As ocupações residenciais predominam nos bairros Pinheiro e Santo André. Encontram-se também nos bairros Rio Branco e Santa Tereza.

\subsubsection{Morros}

Compreendem modelados de dissecação medianamente forte, com topos planos e elevações residuais desnudadas, morros testemunhos delimitados por escarpa íngreme. Nos locais onde há o afloramento rochoso ou a retirada da vegetação, a morfodinâmica possui instabilidade acentuada.

Comparativamente, o Morro do Paula possui um topo plano mais extenso que o Morro das Cabras, o que facilitou a ocupação no local e apesar de possuírem características geológicas semelhantes, até o momento somente no Morro do Paula encontram-se pedreiras instaladas.

\subsection{Alterações no relevo por ação antropogênica}

A intervenção mais expressiva na morfodinâmica natural, considerando a área de estudo ocorre no Morro do Paula, devido à extração de arenito Botucatu. Pode-se destacar que a atividade mineradora provoca mudanças no "balanço geomorfológico", por meio da produção, retirada, transporte e deposição de materiais, dessa forma a pedogênese assim como os processos de intemperismo tornam-se instáveis. A 
fotografia 1 demonstra parte da alteração causada no Morro, sendo que a extração se intensificou aproximadamente há três décadas.

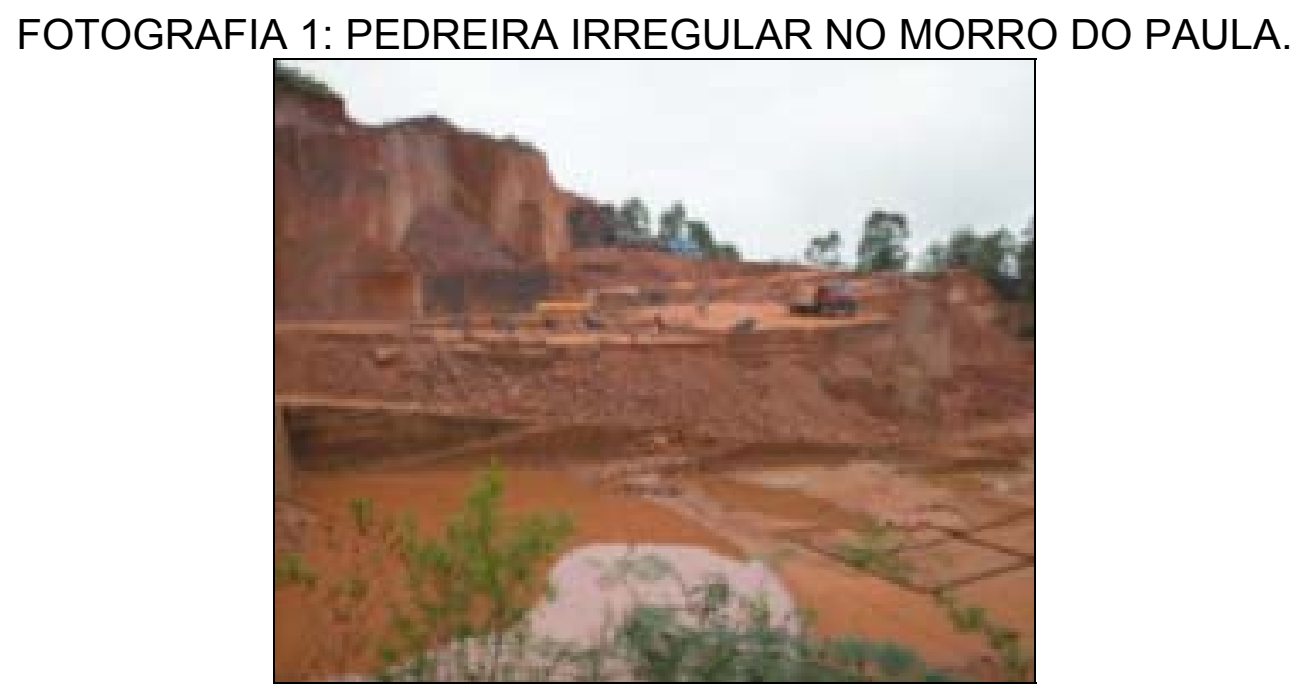

Fonte: SEMMAM, 06/2005.

O "bota-fora" da pedreira jogado tanto na estrada de acesso ao Morro quanto nas escarpas do mesmo, provoca o assoreamento dos cursos de água e a destruição da vegetação, representada neste local pela Floresta Estacional Semidecídua.

\subsection{Alterações na rede hídrica}

A ocupação na planície de inundação do rio dos Sinos, relacionada ao processo inicial de ocupação pelos imigrantes alemães, trouxe aos moradores o problema das enchentes. Na área de estudo, na cidade de São Leopoldo, onde está localizada a foz do arroio Kruze, entre as piores enchentes ocorridas estão a de 1941 e a de 1965. Com o objetivo de resolver o problema, uma expressiva intervenção foi causada à bacia hidrográfica do rio dos Sinos, incluindo a sub-bacia do arroio Kruze que se refere à construção dos diques de proteção iniciada em 1964, por engenheiros alemães.

A construção dos diques resolveu de forma significativa os problemas das enchentes, mas por outro lado houve uma grande diminuição dos banhados, estes servindo como dosadores naturais de água.

Além da construção dos diques, segundo SEMMAM (2006), o arroio Kruze foi canalizado entre os bairros Santo André e Pinheiros, até desaguar no rio dos Sinos. A canalização modificou a dinâmica do ecossistema local, com o rebaixamento do lençol freático e a diminuição dos banhados que se localizavam nas margens do mesmo.

A partir da comparação entre fotografias aéreas de 1991 e de 2002, foi também possível verificar o aterramento de nascentes e canais fluviais.

\section{ANÁLISE DO USO E OCUPAÇÃO DO SOLO}

Os itens identificados no uso e ocupação do solo da área de estudo, estão representadas na figura 4 . 


\section{FIGURA 4: MAPA DE USO E OCUPAÇÃO DO SOLO}

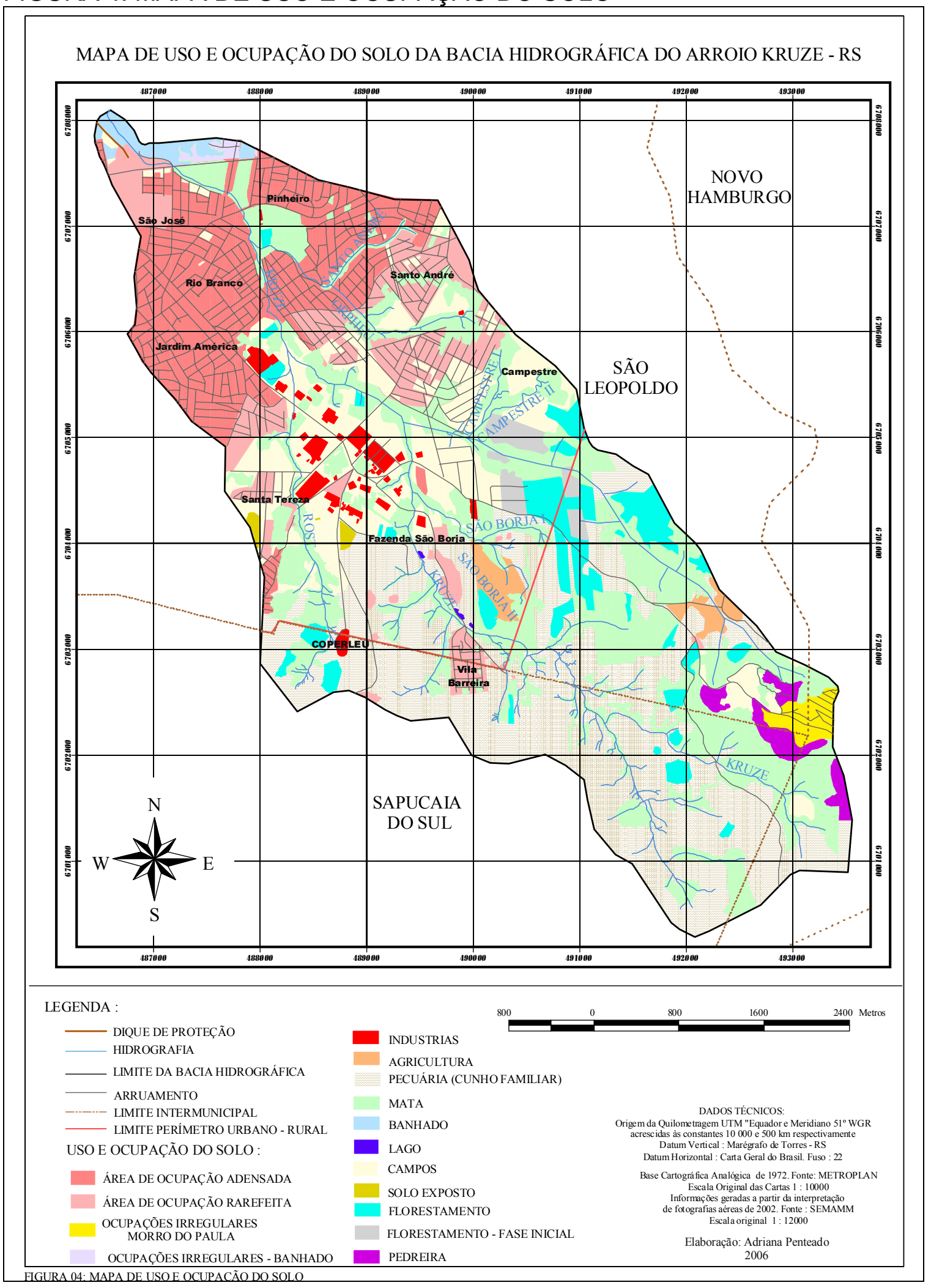

\section{1. Áreas de ocupação rarefeita e áreas de ocupação adensada}

As áreas de ocupação adensada estão localizadas de forma predominante no setor próximo à foz do arroio Kruze (Figura 4). Esse fato está relacionado, entre outros fatores, ao processo histórico de ocupação, caracterizado principalmente pelos imigrantes alemães, que se instalaram as margens do Rio dos Sinos. As ocupações 
adensadas compreendem áreas dos bairros Rio Branco, Jardim América, São José, Santo André e Pinheiro.

Alguns problemas relacionados ao adensamento urbano referem-se à alta taxa de impermeabilização do solo, intensificando problemas de alagamentos e a criação e alteração de microclimas.

As ocupações rarefeitas compreendem áreas dos bairros Santo André, Campestre, Santa Tereza e o final do bairro Fazenda São Borja, principalmente no loteamento da Vila Barreira. Essas ocupações são mais recentes, mas ao longo do tempo podem se tornar áreas adensadas, e assim, sofrer as conseqüências características desse tipo de ocupação.

\subsection{Ocupações irregulares}

Na bacia hidrográfica do arroio Kruze a principal ocupação irregular é a que se encontra no Morro do Paula, seguida da ocupação nas proximidades da foz do arroio Kruze, na planície de inundação do rio dos Sinos, caracterizando-se por ser uma área naturalmente úmida.

As ocupações irregulares no Morro do Paula ganharam maior força a partir da década de 1990 e traz muitos problemas ao poder público. O topo plano do Morro como se verifica na fotografia 2 facilita a ocupação.

O Morro do Paula compreende uma APP - Área de Preservação Permanente, sendo proibido, dessa forma, a criação de infra-estrutura na área.

Porém os moradores do local, mesmo em situação irregular, reivindicam condições mínimas de sobrevivência.

Trava-se o embate entre os ambientalistas que priorizam a preservação do Morro (que compreende um local de beleza cênica) e os políticos que concedem melhorias no local, incentivando assim a vinda de mais moradores. Dessa forma, o problema a cada dia se intensifica sem uma solução coerente tanto do ponto de vista ambiental quanto social.

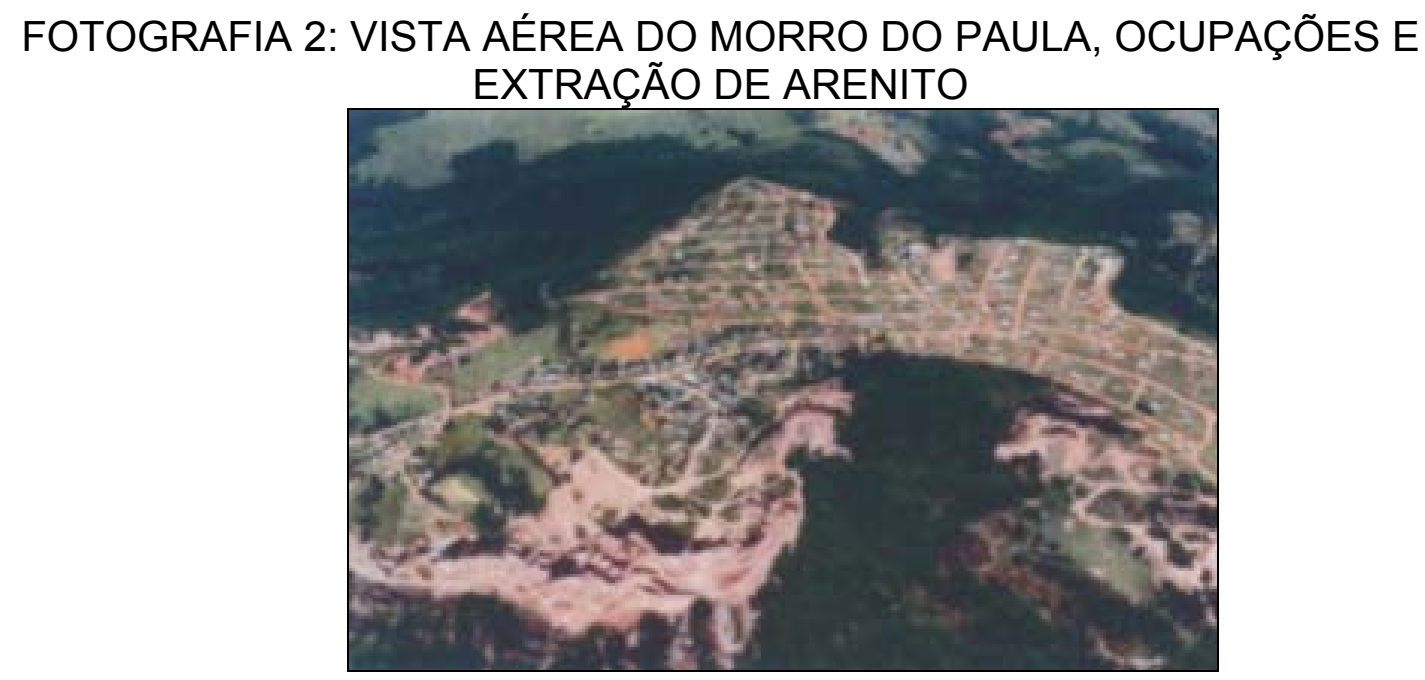

Fonte: Diniz, 2002.

A planície de inundação do rio dos Sinos, que pode ser visualizada de forma parcial na fotografia 3 , compreende uma área úmida muito importante para a manutenção da dinâmica hídrica, da flora e fauna do rio dos Sinos, porém vem sofrendo com ocupações irregulares que promovem o aterro de suas áreas úmidas, retirada da vegetação nativa, e despejo de esgoto de lixo. Na fotografia 3 a linha em azul corresponde ao arroio Kruze desaguando no rio dos Sinos e o polígono em vermelho algumas das ocupações irregulares. 


\section{FOTOGRAFIA 3: OCUPAÇÕES IRREGULARES NA PLANÍCIE DE INUNDAÇÃO DA BACIA HIDROGRÁFICA DO RIO DOS SINOS}

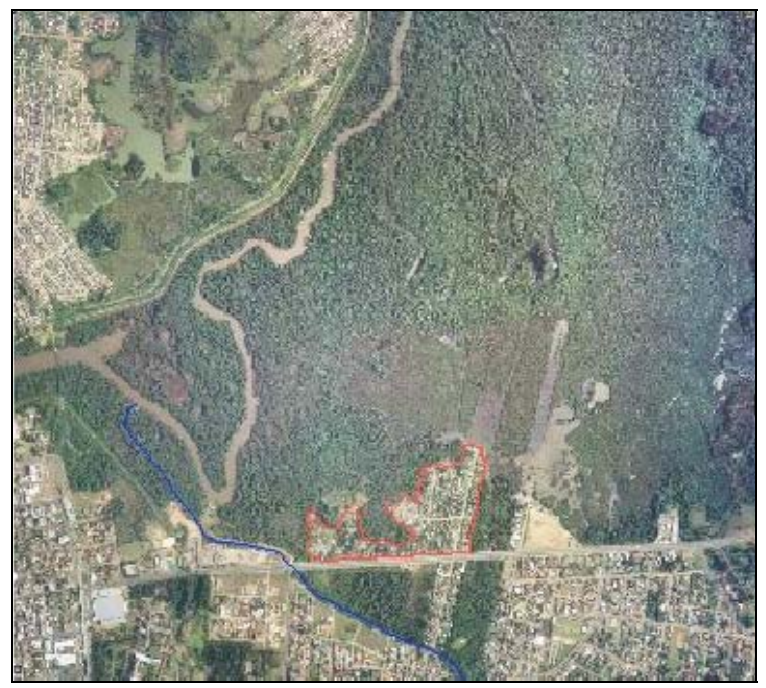

Fonte: SEMMAM, 2005.

\subsection{Banhados}

Segundo SEMMAM (2006), por estar localizado no trecho inferior do rio dos Sinos o município de São Leopoldo possui grande parte de seu território representado por áreas úmidas (banhados). Isto confere ao município uma fisionomia peculiar que serve como abrigo para muitas espécies da fauna, principalmente em períodos reprodutivos, e da flora, possuindo componentes de diversas formações.

Historicamente São Leopoldo conservava seus banhados e pontos de banho ou pesca. Entretanto, após a criação do Sistema de Contenção das Cheias, na década de 1970 , os banhados foram divididos, sendo consideradas protegidas apenas as áreas do interior do dique, onde está localizado o rio, e não as áreas alagadas localizadas do lado externo do mesmo.

\subsection{Indústrias}

Segundo Diniz (2002), em relação às indústrias localizadas na bacia hidrográfica do arroio Kruze, as principais são do ramo metal - mecânico, plástico, borracha, calçadista, papel e cerâmica. Muitas delas, apesar das leis e fiscalizações, são pontos de poluição da bacia hidrográfica do arroio Kruze.

Segundo SEMMAM (2005), no vale do rio dos Sinos os impactos mais significativos sobre a rede hidrográfica são causados pela grande concentração de indústrias instaladas na região. De forma geral, a poluição hídrica é provocada principalmente pela inexistência ou subdimensionamento das estações de tratamento de efluentes líquidos das indústrias, não respeitando os parâmetros expressos na legislação. Com isso, efluentes contendo metais pesados, altas cargas orgânicas, entre outros, são lançadas nos arroios e no rio dos Sinos.

\subsection{Agricultura e pecuária de cunho familiar}

A agricultura e a pecuária na área de estudo não possui grande representatividade comercial, prevalecendo à produção de cunho familiar. Os solos da região são pobres e, dessa forma, para uma produção em maior escala, a adoção de 
técnicas conservacionistas adequadas, bem como a calagem e as adubações químicas e orgânicas, constituem práticas fundamentais para o aproveitamento desses solos.

Atualmente parte expressiva dos solos da área de estudo são utilizados para o florestamento de acácia e eucalipto.

\subsection{Campos}

No Brasil, reconhecidamente um dos países com a maior biodiversidade do mundo, ecossistemas como dos campos da região sul estão na eminência de desaparecer, pois estão restritos a pequenos fragmentos. A viabilidade de conservação dessas áreas se constitui numa incógnita, tendo em vista que muitas se encontram em áreas particulares.

Das intervenções causadas nas áreas de campo, três seriam as principais: o desmatamento, o pastoreio e o sistema de cultura escolhido, que nem sempre é favorável a preservação dos solos (VERDUM, 2004).

\subsection{Florestamento}

Em 1956 no Rio Grande do Sul, com a aprovação da lei de incentivos fiscais, houve um grande estímulo à atividade de florestamento no Brasil. Essa atividade teve, como um dos principais objetivos, o fornecimento de matéria-prima para a indústria de celulose e papel ${ }^{3}$.

Como conseqüência, enquanto em 1990 restava somente $2 \%$ de mata nativa no estado, no mesmo período havia praticamente o dobro de florestamento de acácia, eucalipto e, principalmente, pinus. As maiores concentrações desses cultivos encontram-se ao longo da BR 290, na bacia do rio Jacuí (da qual o rio dos Sinos é afluente).

Segundo bibliografia mundial, a monocultura de eucalipto, especialmente, causa erosão e degradação do solo, além da alteração no regime hídrico dos aqüíferos superficiais e subsuperficiais. O eucalipto se adapta mais facilmente em solos de baixa fertilidade, talvez isso explique a ocorrência significativa de florestamento em toda a área da bacia.

\subsection{Vegetação arbórea - Mata}

A vegetação arbórea em resquícios encontra-se distribuída em toda a bacia hidrográfica do arroio Kruze, com concentrações maiores no perímetro rural.

Segundo Diniz (2002), originalmente, na bacia hidrográfica do arroio Kruze, eram encontradas formações florestais densas nos locais de solos mais profundos e férteis. Atualmente, a vegetação arbórea encontra-se misturada à vegetação herbácea campestre, onde os solos rasos impedem a formação de uma vegetação mais

\footnotetext{
${ }^{3}$ Em reportagem do SBT - Rio Grande 29/06/06: destacou-se a instalação da Aracruz Celulose, no município de Guaíba, região metropolitana de Porto Alegre. Sendo que a mesma deve começar a funcionar entre 2010 e 2015. Como de praxe, na reportagem, foram frisados os números de empregos que serão gerados pela Aracruz, sem mencionar quais poderão ser os prejuízos ambientais no estado. Além disso, atualmente, a Aracruz divulga propaganda em rede nacional com artistas globais destacando "Aracruz fazendo um papel bonito lá fora". Mas o que ela busca é usar sua "boa imagem", para encobrir violações que tem cometido a mais de trinta anos contra comunidades indígenas, quilombolas, camponeses, entre outras. Em junho deste ano, aproveitando feriado prolongado, mandou desmatar uma área de Mata Atlântica na comunidade Jacutinga, Norte do Espírito Santo. A empresa mobilizou sete tratores e foi detida por uma comunidade local, que defende a preservação da mata há pelo menos vinte anos. As primeiras reações da Aracruz foram chamar a polícia para dar proteção às suas maquinas, e em seguida, colocar sua guarda particular, a Visel. Segundo os agricultores do local, a Aracruz esta tentando agora agir durante a noite. Fonte : Rede Alerta contra o Deserto Verde - 20 de junho de 2006.
} 
Revista Eletrônica Geografar, Curitiba, v.1, n.1, p. 01-19, jul./dez. 2006

exuberante. Atualmente a vegetação encontra-se profundamente alterada pelas ações antrópicas.

A partir da analise do mapa das transgressões ao Código Florestal (Figura 5), verificou-se que de forma geral, a vegetação ciliar é descontínua em toda a bacia e que os locais onde a mesma está presente, em geral não correspondem ao mínimo de 30 metros.

Em relação às nascentes, a maioria não possui o mínimo de vegetação sugerido, pois das 143 nascentes, menos de 10\% encontram-se totalmente preservadas. A parte mais prejudicada diz respeito aos rios com nascentes em Sapucaia do Sul.

\section{FIGURA 5: MAPA DE VEGETAÇÃO ARBÓREA E HERBÁCEA}

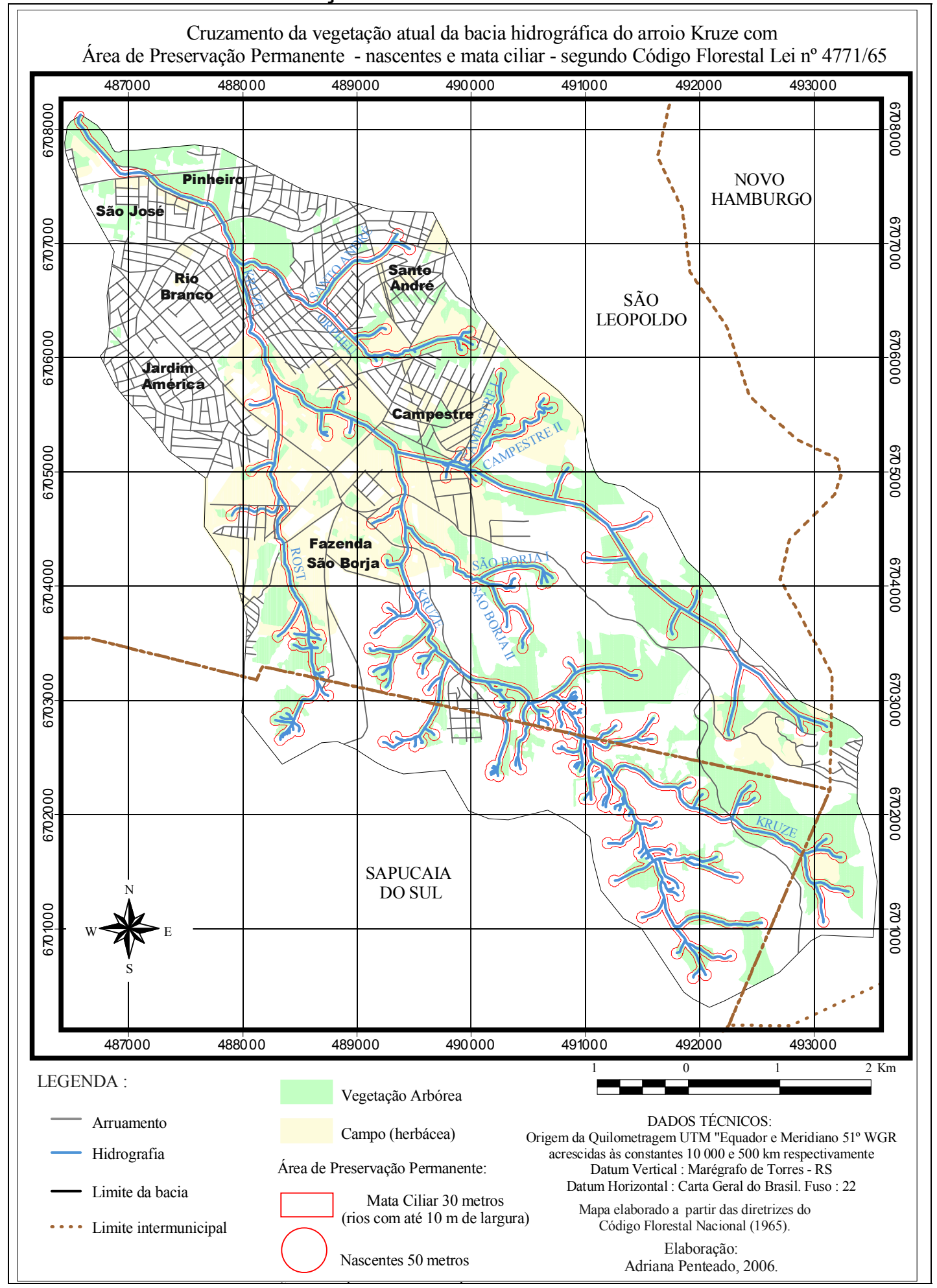




\subsection{Questões relativas à qualidade da água}

Segundo Ramos (2005), o rio dos Sinos é tido como altamente poluído, tanto pelo lançamento "in natura" de esgotos domésticos de cidades e vilas quanto pelo lançamento de resíduos industriais sem prévio tratamento. Tais lançamentos têm exercido influência crescente na poluição da água, exigindo, cada vez mais, tratamento rigoroso para que esta água seja distribuída à população na forma potável. Também o enorme volume de lixo depositado nas depressões e áreas baixas contribui direta e indiretamente para a poluição da água.

Estes problemas característicos da bacia hidrográfica do rio dos Sinos são encontrados, em menor escala, na sub-bacia hidrográfica do arroio Kruze.

O tratamento de esgoto, quando existe, muitas vezes conta com estações de tratamento pouco eficientes. É o que acontece, por exemplo, na Estação de Tratamento de Esgoto- ETE de São Leopoldo, compreendendo a única estação de tratamento dos municípios da área de estudo e apesar de pouco eficiente, inclui o município em um dos poucos que tem tratamento de esgoto no Rio Grande do Sul.

Segundo Sincler Gonçalves ${ }^{4}$, técnico em Tratamento de Resíduos, na estação entra cerca de $100 \mathrm{l} / \mathrm{s}$ de água, esta com classe quatro e após o tratamento a água continua com classe quatro, pois a quantidade de coliformes fecais, nitrogênio e fósforo são iguais, havendo apenas a diminuição dos valores de Demanda Bioquímica de Oxigênio - DBO e da Demanda Química de Oxigênio - DQO em mais ou menos 80 $\%$ e $70 \%$, respectivamente. Nestas condições São Leopoldo trata cerca de $20 \%$ de seu esgoto. A Resolução CONAMA nº 003 de 05 de junho de 1984, estabeleceu a classificação das águas doces, salobras e salinas do Território Nacional, de acordo com a Resolução $n^{\circ} 20$, de 18 de junho de 1986. Esta classificação estabelece os usos da água a partir da qualidade da mesma. Dentro da classificação Águas Doces, existem cinco subdivisões; Classe Especial, Classe 1, 2, 3 e 4. As águas de Classe 4 devem ser destinadas à navegação, harmonia paisagística e aos usos menos exigentes. Constituindo-se dentro deste parâmetro a água de pior qualidade.

\section{CONSIDERAÇÕES FINAIS}

Em relação aos principais aspectos físicos da bacia hidrográfica do arroio Kruze, o relevo apresenta-se predominantemente de forma suave e suave ondulado, com diferença altimétrica variando em torno de 300 metros, os solos são naturalmente pobres para fins agrícolas, com presença em grande parte do horizonte B textural, fator que facilita a erosão.

Os aspectos físicos característicos da área relacionados ao uso e ocupação do solo, de forma muitas vezes inadequado, conferem ao local problemas como; intenso processo erosivo causando assoreamento dos cursos de água, destruição de importantes áreas verdes devido a ocupações irregulares em locais de extrema riqueza biológica, tais como os banhados e o Morro do Paula. A pressão urbana cada vez mais latente vem aumentando a poluição e mudança na morfologia da rede hídrica, além de criação de microclimas locais.

No perímetro rural os solos são utilizados de forma expressiva como áreas de reflorestamento, isto pode diminuir a vazão dos cursos hídricos, além de estarem avançando em locais de vegetação nativa.

O pleno desenvolvimento de uma determinada região está relacionado em primeiro lugar diretamente ao total conhecimento dos recursos naturais, humanos e econômicos disponíveis e, numa fase seguinte, a racional utilização desses recursos.

\footnotetext{
${ }^{4}$ Entrevistado em dezembro de 2005.
} 
A bacia hidrográfica do arroio Kruze está localizada entre três municípios da região metropolitana de Porto Alegre, isto exige o diálogo entre diferentes entidades e a comunidade, sendo necessário, muitas vezes, transpor os limites político administrativos de um município.

Os problemas encontrados na bacia hidrográfica do arroio Kruze compreendem questões que ultrapassam seus limites, e em maior ou menor escala são identificados em toda a bacia hidrográfica do rio dos Sinos.

\section{REFERÊNCIAS}

BOTELHO, R. G. M. Planejamento ambiental em microbacia hidrográfica. In: Erosão e Conservação dos Solos - conceitos, temas e aplicações. A. J. T. GUERRA, A. S. SILVA \& R. G. M. BOTELHO (Orgs.). Rio de Janeiro: Bertrand Brasil, 1999.

CÓDIGO FLORESTAL. Lei $\mathbf{n}^{\circ} \mathbf{4 7 7 1}$ de 1965.

CONAMA - Conselho Nacional de Meio Ambiente. Estabelece a classificação das águas doces, salobras e salinas do Território Nacional, Resolução $\mathbf{n}^{\circ} \mathbf{2 0}$ de 18 de junho de 1986.

DINIZ, E. D. P. Diagnóstico Ambiental da Bacia Hidrográfica do Arroio Kruze. Canoas, 2002. 212 f. Dissertação de Mestrado, Universidade Luterana do Brasil.

EMBRAPA. Centro Nacional de Pesquisas de Solos. Sistema Brasileiro de Classificação de Solos. Brasília : SPI, 1999.

FRANK, H. T. Geologia e Geomorfologia das Folhas Morretes, São Leopoldo, São Jerônimo, Guaíba e Arroio dos Ratos - RS. Porto Alegre, 1989. 160 f. Dissertação de Mestrado, Universidade Federal do Rio Grande do Sul.

PROJETO RADAMBRASIL. Folha SH 22 Porto Alegre e parte das Folhas SH 21 Uruguaiana e SI 22 Lagoa Mirim. Rio de Janeiro: IBGE, 1986.

RAMOS, E. M. Aspectos Geográficos e Geológicos da Região Metropolitana de Porto Alegre (Norte). Porto Alegre, 1975. 106 f. Dissertação de Mestrado, Universidade Federal do Rio Grande do Sul.

ROSS, J. L. S. Geomorfologia: ambiente e planejamento. São Paulo: Contexto, 1994.

SEMMAM - Secretaria Municipal de Meio Ambiente. Subsídios para o Diagnóstico Técnico sobre o município de São Leopoldo. Primeira etapa do Plano Diretor Aspectos Ambientais. São Leopoldo: SEMMAM, 2006.

STRAHLER, A. N. Hypsometric (area-altitude) analysis of erosional topography. Geol. Soc. America Bulletin, 1952.

VERDUM, R.; BASSO, L. A.; SUERTEGARAY, D. M. A. (Orgs.) Rio Grande do Sul. Paisagens e Territórios em Transformação. Porto Alegre: UFRGS, 2004. 